\title{
Representation Of Modern Tarling Music Amidst Cultural Relation and New Media Era
}

\author{
Khaerudin Imawan ${ }^{1}$, Nurul Chamidah ${ }^{2}$ \\ imawan7@gmail.com ${ }^{1}$,nurul.chamidah@mail.ugm.ac.id ${ }^{2}$
}

Universitas Gajah Mada

\begin{abstract}
Modern tarling has become a contestation of the present music artists to explore arts amidst the development of technology and the flow of modernization. Modern tarling is preferring the establishments of political-economy relation, identity of youngsters as subculture, emotional and psychological reactions, relation between art and family as well as perceiving tarling as commercial entertainment industry in which those establishments have constructed modern tarling music art as the representation of popular culture of Pantura community.The modification of music instruments, performance innovation and collaboration of tarling singer with the other music genres on stage with a complete multimedia background and choreographer contribution/role. Converting the album into file and immense reproduction effort conducted by fans for tarling has emerged audiovisual product which distributed freely in cyberspace. This research uses qualitative methods with a critical paradigm, views of Stuart Hall and Paddy Whannel with their model of style music circuit has restricted this research to be capable of describing the relation between popular music with the other scopes which interrelated as the manifestation of modern culture representation.
\end{abstract}

Keywords: New Media, Tarling Music, Representation, Cultural Relation.

\section{Introduction}

Tarling music has experienced continuous changes from time to time because the nature of tarling art is the art which not originated from keraton palace that has its own pakem. Tarling art was born among the people. It was assumed to has been born since the 1930s decade and continued to grow until the present era by experiencing various changes, including the songs. Reviewed from its development since 1960s decade, the tarling songs have begun to changed. At the beginning, it only consisted of classical songs which commonly played along with gamelan. Its popular actors are Jayana, Abdul Ajib, Sunarto, Uci Sanusi, Dariyah, Askadi, and others. Since the decade of 1960s, a change has emerged through a quite rapid rhymes which according to H. Abdul Adjib is called as "kiser gancang". Since then, the songs were changing due to the influence of national dangdut music[1].

The decreasing numbers of show and spectators of Tarling art have made the artists to seek for alternative to stay exist. Each gig always used by them to produce video materials which later uploaded to YouTube. Inevitably, the productions of visual material outside the scheduled gigs are conducted as well. Through this method, the existence of Tarling art adapts itself to conduct visual material production as the promotional message which makes the Tarling art to be watchable by YouTube visitors or the social media users. 
The phenomena of modern tarling music art which presented on entertainment stages, now have experienced a modification or being represented through visual audio production in the form of song album that give birth to popular music culture. According to Stuart Hall, culture is about shared meaning[2] and representation is a central process in the production process of culture. Language in this context is the lyrics of tarling songs as the main instrument where we feel something, and where the meaning is produced and exchanged. Meaning could only be accessed with our accesses towards language. In that order, according to Hall, language is an important element on meaning and culture.

Language is able to do it because it works on representation system[2]. In language, we use sign or symbol, either in the forms of voice, printed words, electronically-produced images, musical tones, or an event to stand for or presenting the others about the concept, idea, and the feeling of ours. Language is a media in which the concept, idea, and feeling are represented in culture. Representation towards language is a central process in a process of how the language is produced. Language is a representation system. The words delivered through voice, language written through words, musical language uses note and musical scale, body language uses physical gesture, fashion industry uses an item of clothes, facial expression language uses the way to organize facial expression, television in digital or electronic method produces dots and images on screen, traffic light uses red, yellow, and green to 'express something'. Elements like voice, words, notes, gestures, expressions, and clothes are the parts of musical art[3].

Deriving the concept of Stuart Hall above, thus, the important role of tarling music art on language is the function of tarling in stand for or representing a concept, idea, or feeling on stage. The singers of modern tarling music have their own characteristics of how they conceive their own concepts about the world of stage started from the roles and characters of singers, the quality of sound system, and entire performances of team during the thrumming of guitar, the blowing of flute, and when the fingers are pressing the tuts of organ keyboard. Combined with the hands that pound the drum until harmonious sound with tarling typical rhyme is heard. Based on this background, then, how tarling music plays important role, what is the correlation of culture and art values which present as the manifestation of the cultural representation of modern community.

\section{Results}

\subsection{Modern Tarling Music as the Cultural Representation of Modern Community}

The shifting of a culture of community in a region from its environment is caused by the emergence of new culture which assumed as more attractive, flexible, and easy to understand by most of the community, even the community with low social status will be able to easily implement it into their life activities. A term of "Pop Culture" in which the actualization of this culture is gaining support from the utilization of high-technology device, therefore, its distribution is rapid and accurate as well as obtaining responses from most of the community circles. This flourishing and rapidly growing culture gain significant development in the urban community and its existence is influential towards the life of city teenagers.

In the perspective of Leavis and Mazab Frankfurt, it is mentioned that pop culture perceives the commodity-based culture as inauthentic, manipulative, and unsatisfying. This argument conveys that the capitalist mass culture which modified is inauthentic because it is not produced by people/community, manipulative because the main purpose is to be bought and unsatisfying because besides easy to be consumed, it does not require a lot of work and failed to enrich the consumers[4]. 
In the perspective of culture industry, "popular culture is the culture which born due to the will of media [5]. This argument considers that media have produced various types of popular culture product which influenced by import habit and the results have been distributed through global network of media, therefore, the community has been unconsciously absorbing them [6].

The explanation regarding popular culture also described various definitions regarding pop culture has been compiled from various perspectives which discuss about the issue. At present, the important values of pop music which certainly conceive cultural and economic natures have brought them as the central focus in cultural studies. Referring to the views of Hall and Whennel in Introducing Stuart Hall: The Importance and Re-evaluation of Popular Mass Culture, they provide explanation regarding the relation between music style and the other aspects, including on the circuit model as follows[2].

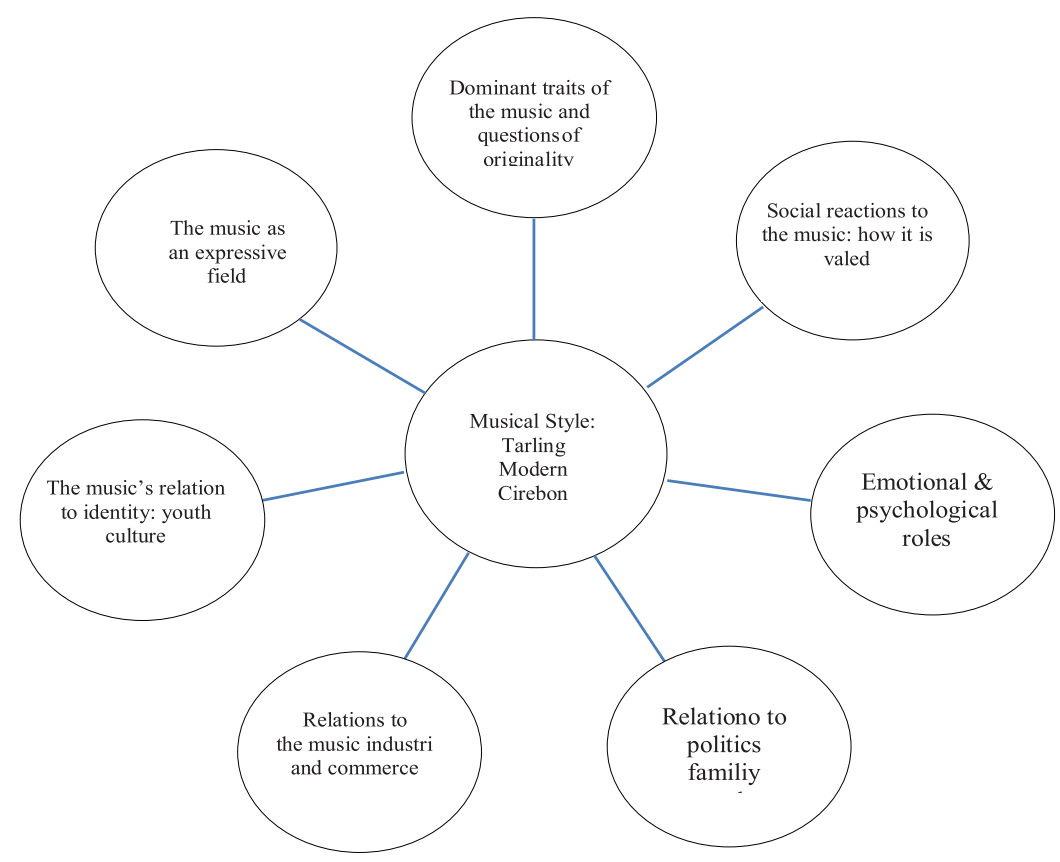

Fig. 1. Graphic of Circuit Musical Style Stuart Hall and Paddy Whannel (1964).

In the record of Indramayu's humanist, Supali Kasim, the existence of tarling art is inseparable from the functions that come with it. In general, an art is correlating with the sides of education, enlightenment, and entertainment. In specific context, Tarling has function as the creation media, namely the creation creativity since the emergence of tarling art, musical creation, songs creation, and creation of drama. Tarling also works as expression media which includes the anxiety of social strata, love, or the other communities. And not less important, tarling plays role as education which might have community educational values through songs and drama.

Tarling is one of the types of indigenous art in which the songs have unique characteristics, either from the music composition, song material, and the development. This condition has been quite interesting to be made as research and analysis material in aim to understand its existence in the environment of the supporting community. Tarling as the intellectual artwork of Cirebon typical music has generated contribution in promoting the 
cultural values of Cirebon in which its development is assumed to experience changes of form and the expressing method. Those changes are indicated by varied types of rhyme of Tarling music, namely classic, dangdut tarling, pop, and disco tarling. For some observers/enthusiasts of Cirebon's art, Classic tarling is considered as the identity music and melodic personality of the Shrimp City (the nickname of Cirebon City). By implementing the perspective of Hall and Whennel to inspect in obvious manner, the relation of popular music with interconnected scopes in accordance with the model of music style circuit can be explained through the research discussion as follows.

\subsection{Dominant Character of Tarling Music and Its Originality}

Dominant character of modern tarling music is inseparable from the role of modern tarling singers which in general have their own concepts of how they sing the trendy modern tarling song with their typical characteristics. Although sometimes, those typical characteristics which have been booming and accepted in the hearts of the spectators are frequently become the references for fans or the other singers to conduct duplication. For example, Diana Sastra as modern tarling singer her unique characteristics or her artworks are sometimes imitated by the fans or the other singers.

This condition has made Diana Sastra to keep performing innovation and creativity to produce new unique/typical characteristics. Establishing an image on stage to acquire unique characteristics is not an easy job and cannot be done individually by only focusing on the singers themselves. The strengths of the surrounding/supporting team have to be solid to be able to produce new artworks and creations. The concepts of innovation and creativity have to be maturely planned, although sometimes they just occur during the break.

Askadi Sastrasuganda has told a story in which before inventing tarling art, at the beginning, Jayana was only a monolog who frequently tells the story of Cirebon's people with the sound of flute blew by a Barang, a Chinese citizen who has been settling in Cirebon. At that time, Jayana fills his monolog with harp and flute. However, the role of harp has been replaced with guitar due to its slimmer shape and easy to be carried around. Since then, the combination of guitar and flute has accompanied Jayana in performing monolog with Cirebon language. Not as complicated as the love or politic stories today, Jayana's monolog is more able to hypnotize the spectators who sit on mats with the theme of daily life. The expertise of Jayana regarding his monolog has been acknowledged as capable of making the audiences/spectators to feel the story behind his life, touching, inspiring; although sometimes delivered in a quite ecstatic way which bursts the laugh of the audiences

The development of tarling at present is seems to be more dynamic, with modification of musical instruments and the performance innovation on stage by involving multi-talent artist. Multimedia background is presented, nayaga plays the drum and gamelan, sinden and tarling singers themselves, and including the role of a choreographer.

\subsection{Social Relation Towards Music During the Singing of Tarling}

The tarling arts in the past and present are really different. Modern tarling in the era of its birth which near the 2000s has become more popular in the northern coast of Java. Especially in Jatibarang, Indramayu, and Cirebon. Tarling was determined as the name because the dominant instruments are guitar and flute. Tarling is basically a musical show combined with short drama. However, expanding popularity of dangdut in 90s has made the tarling artists to 
include the element of dangdut in the show. Since then, the term of 'modern tarling' has emerged.

The modern tarling artists continue to occur along with the easiness of acquiring stages. Not only the entertainment stages for particular events, audition stage in television or the stage in cyber world have enlightened the entertainment world of modern tarling. Besides easy to be produced, varied options of software that flooded the virtual world have made the booming of entertainment art of modern tarling. It also generates many grouped fans in various segments. The fever of creation and innovation as well as collaboration of tarling music art which played on the stage are massively produced as well for financial/profit reason.

\subsection{Emotional and Psychological Roles of Modern Tarling}

The problems which occur when tarling keeps rattling is the desire of the audiences. Sinden just showed herself delivering one song, at the same time, the audiences get on the stage and dancing. This kind of behavior from the audiences which according to Askardi that ruins tarling art show. The irony is when tarling has gained more interest and invited to celebration events, some audiences are drunk and dancing on the stage with the smell of arrack (Cap Motor). The smell of liquor which comes from the mouth of the audiences who dancing that ruins the show of tarling. The way of the drunk people dance has offended the Sinden as well. Witnessing this kind of show, many audiences leave the show arena.

Although through different method and genre, she attempts to made tarling music art as not merely a show, but as the artwork which has local wisdom values. As tarling singer, Diana Strata has not denied that every time she goes on stage, she expects tips from the audiences. Based on that, she tries to become a professional by providing maximum performance, attempting to give the best for the audience to obtain satisfaction from the entertainment on stage. The responses from the audiences are very anticipated as the standard whether the tarling songs are accepted or not by them in their hearts. Based on the responses of the audiences, she conducts various improvisations to reach the peak of satisfaction in enjoying tarling art entertainment.

\subsection{The Correlation with Politic and Employment Sector of Family}

Politic enters different moment in creating pop music through production, distribution, performance, consumption, and others. At the level of 'common sense', political pop is truly political type of pop which contains open political commendation about the world. Politic is highly correlated to authority/power, and pop music might have immense power. Pop music can be politic if the musicians are said so. The communities which have specific tastes could become a political constituent. Music industry has its own definition of political pop music; politic pop as the selling category. Some of pop music are marketed due to their political nature. Another definition regarding political pop music is pop music which organized in political manner. Calling pop music as having political nature means that the varied meanings are being brought to be played. Pop music can be simultaneously containing politic through various methods.

\subsection{Tarling Music as Expressive Sector}

Regarding the mastery of tarling art, modern tarling singers confess that they still feel unsatisfied and want to keep learning to the senior artists who inherited classic tarling art. According to them, Tarling art is really vast, not only regarding the ways of playing guitar and 
flute but more about the management on stage. They are keep exploring classic tarling songs, from the lyrics, and the mastery on stage. In order to be able of naturally playing classic tarling, modern tarling singers admit that they still have much to learn. Until present, they tend to perform modification of classic tarling with the modern genre of semi dangdut combination. Then, along with the developments of world stage and technology device, tarling has started to slowly shifting from semi dangdut to tarling dangdut which played live with organ. Since then, tarling dangdut with the combination of organ has become a hit with a lot of fans.

Modern tarling singers are still holding ecstatic and cultural values of the community where the tarling itself has been growing. They are being reluctant to sell minimum clothes and sexy dance. For the modern tarling singers, those two things are insufficient to be able to survive. The most important thing is good voice and song as well as attractive performance on the luxurious stage. If those work, she believes that the fans will get on stage without being invited and willingly give their tips. She confesses that the competitions are getting tighter. There are many singers in her group which have decided to leave and build their own tarling group. However, she is delightful to see the expansion of tarling dangdut music. Nowadays, Diana herself has started to perform in national television.

\subsection{Tarling Music and Teenagers}

The relation of modern tarling music with the circle of teenager is inseparable with the role of the tarling singers. Not only having singing potential, emotional closeness with the fans which established by singers during the performance on stage or beyond the stage is determining into what extent tarling is favored by teenagers. The shifting or classic tarling to modern tarling or single organ dangdut is targeting different market segment. If in the past, the majority of the audience of tarling are adults or parents, now, the show of modern tarling has turned into the opposite. On each gig event, the audiences of modern tarling are instead dominated by teenagers and youngsters. The age of audiences of tarling is more varied. The numerous productions of tarling song in the forms of album, music files such as MP3 and immense reproduction effort of tarling into audio visual products which distributed freely in cyber world including YouTube and social network have made the booming of tarling in the circle of teenagers/youngsters.

\subsection{Tarling Amidst Industry and Commercial}

This modern tarling singer has her own story of how she distributes her artworks. The albums produced by her have their own market segment. Selling the album directly towards the audiences during live performances. Not in cassette stores or roadside stalls which have to compete with the other music products that already have famous label. If she forced to rely on the selling of albums in store, it's not a sure thing that in one day the albums will sold to dozens of copies. Diana Sastra has chosen to sell tape album in person or distributing it by partnering with a promoted product. Although, some of her fans are purchasing the albums directly to distribute it towards stores. As the time goes, a lot of original tape store has closed, beaten by online trading. The buyers only need to search their desired song and the file format will be easily download. 


\section{Conclusion}

Tarling art is inseparable from its original identity as artwork which continues to experience updates due to the influence of dominant character of popular music. This research has proven that the existence of the resistance of modern tarling music which goes beyond the classic grip, no longer considering the aesthetic values characterized by honorable culture. Goes beyond the classic grip, changing the song lyric, presenting the other music instruments, dare to collaborating with different genres and open towards production model have made modern tarling art to positioned itself as sub culture which capable of reconstructing the form of classic art in popular culture. From the framework of the concept of Stuart Hall can be concluded that about tarling another manifestation of its resistance is that modern tarling music is dare to run from the reality in which classic tarling is considered as honorable culture that unable to lift their prestige and dignity in economic context and social strata amidst the modern community. The performance of tarling singer is more dynamic. The existence of digital era and new media has converted the production method of modern tarling art into another form. The visualization of tarling artwork is capable of providing easiness for modern tarling fans to gain ease of access in enjoying the artwork of modern tarling.

\section{References}

[1] L. Raja, "Sejarah Musik Tarling, Sebuahh Seni Musik yang Menyiratkan Pesan Moral." 2017.

[2] S. Hall, Culture, Media, Language. Hutchinson, London, 1981.

[3] and Y. Mesti, Rian, "Cultural Representation (Re-presentasi Budaya)," 2013. .

[4] C. Barker, "Cultural Studies Teori dan Praktek.” Kreasi Wacana, Yogyakarta, 2000.

[5] David Walton, Introducing Cultural Studies Learning through Practice. University of Murcia, Spain: Sage Publications, 2008.

[6] J. Fiske, Cultural and Communication Studies: Sebuah Pengantar Paling Komprehensif. 2004. 